Research Report No. 29/2007

\title{
What's Democracy Got to Do With It?: A Critique of Liberal Constitutionalism
}

\author{
Allan Hutchinson \\ Osgoode Hall Law School of York University, ahutchinson@osgoode.yorku.ca \\ Joel I. Colón-Ríos
}

Follow this and additional works at: http://digitalcommons.osgoode.yorku.ca/clpe

\section{Recommended Citation}

Hutchinson, Allan and Colón-Ríos, Joel I., "What's Democracy Got to Do With It?: A Critique of Liberal Constitutionalism" (2007). Comparative Research in Law \& Political Economy. Research Paper No. 29/2007.

http://digitalcommons.osgoode.yorku.ca/clpe/245 


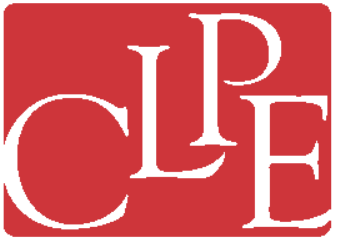

\section{Comparative Research in Law \& Political Economy}

Allan C. Hutchinson and Joel Colon-Rios

What's Democracy Got To Do With It? A Critique of Liberal Constitutionalism

EDITORS: Peer Zumbansen (Osgoode Hall Law School, Toronto, Director, Comparative Research in Law and Political Economy, York University), John W. Cioffi (University of California at Riverside), Lindsay Krauss (Osgoode Hall Law School, Toronto, Production Editor) 


\title{
Victoria University of Wellington Legal Research Papers
}

\author{
Editor, Professor John Prebble \\ Assistant Editor, Laura Lincoln
}

Volume 3 Issue No 5, 2013

\section{WHAT'S DEMOCRACY GOT TO DO WITH IT? A CRITIQUE OF LIBERAL CONSTITUTIONALISM \\ ALLAN HutCHINSON \\ JOEL I. COLÓN-RÍOS}
Victoria University of Wellington Faculty of Law Research Papers are available by volume and issue number at: http://www.victoria.ac.nz/law/research/default.aspx .


CLPE Research Paper 29/2007

Vol. 03 No. 04 (2007)

\title{
Allan C. Hutchinson and Joel Colon-Rios \\ WHAT'S DEMOCRACY Got TO Do WiTh IT? A CRITIQUE OF LIBERAL CONSTITUTIONALISM
}

\begin{abstract}
This paper examines the extent to which Ronald Dworkin's liberal constitutionalism, as presented in his recent work Is Democracy Possible Here? Principles for a New Political Debate, can provide the basis and impetus for the realization of democracy in contemporary societies. The paper is divided into three main sections. We begin by locating the broader institutional contexts within which debates about the importance and salience of democratic politics have taken place and introducing Dworkin's distinctive and defiant contribution to those debates. In the second and main section, we offer a substantial critique of Dworkin's proposals and demonstrate how his (and fellow constitutionalists') liberal project may be as much a part of the problem as the solution. That critique is divided into four parts; it includes a series of philosophical, political, constitutional, and historical arguments against the democratic credentials of Dworkin's project. The third section explores a different approach to how democracy can be more effectively and fully mobilized to meet present-day challenges; the emphasis here is on more affirmative and constructive proposals. By way of conclusion, we speculate on the directions that further efforts might take to fulfill the promise of democratic politics in contemporary societies. We maintain that, if democracy is to be realizable, then it needs to be of a more robust and less derivative kind than Dworkin's liberal project envisages. Rather than arguing that any remnants of constitutionalism should be abandoned, we propose to re-dress as we challenge the supposed balance between constitutionalism and democracy and, in its place, combine a strong democracy with a weak constitutionalism.
\end{abstract}

Keywords: democracy, liberal constitutionalism, Dworkin

JEL classification: K39 
Author Contact:

Allan C. Hutchinson

Osgoode Hall Law School, York University 4700 Keele St., Toronto ON, Canada, M3J 1P3

Email: ahutchinson@osgoode.yorku.ca

Joel Colon-Rios

Osgoode Hall Law School, York University

4700 Keele St., Toronto ON, Canada, M3J 1P3

Email: joelcolon-rios@osgoode.yorku.ca 


\title{
What's DEMOCRACY Got To Do WiTh It? A CRITIQUe OF LiBERAL CONSTITUTIONALISM
}

\author{
By Allan C. Hutchinson and Joel Colon-Rios*
} "Democracy forever teases us with the contrast between its ideals and its realities,
between its heroic possibilities and its sorry achievements"

- Agnes Repplier

\section{INTRODUCTION}

Democracy seems to be in trouble. It is not only struggling to win new national recruits in the world, but it is having grave difficulty in those nations where it is already considered to be established and enabling. This is particularly true of those Old World states who are intent on promoting its benefits to more sceptical New World countries: domestic threats to democratic practices and ideals threaten to undermine the whole appeal and exemplar of democratic government. Moreover, this seeming crisis is mirrored by the state of democratic theorising. Commentators and scholars lock horns over what is and is not demanded by a genuine commitment to democratic governance. In particular, the fundamental tensions between security and freedom, stability and change, and representative and popular participation have become more evident and acute. From all sides of the political spectrum, there is a crisis of confidence in the capacity of democracy alone to meet the challenges of the modern age. Indeed, there seems to be a deep anxiety that, while democracy has a role to play in contemporary governance, there are definite limits to its provenance and authority. In short, debate rages over the extent to which democracy has to be confined and circumscribed in the name of some larger and more encompassing political ideal.

Although Ronald Dworkin has been at the forefront of modern liberalism in the past 40 years, he has spoken little directly about democracy. Applying his own brand of rigorous philosophical analysis to recalcitrant

\footnotetext{
* Distinguished Research Professor and Lecturer, Osgoode Hall Law School, York University, Toronto. We are grateful to Leslie Green, Nicola Lacey, Martin Hevia, Ron Podolny, and Diana Younes for their critical comments and helpful suggestions.
} 
problems of law and politics, he has flown the flag for a consistent and progressive mode of liberal commitment; there are few hot-button issues which he has not tackled and to which he has not brought an illuminating stance. However, in his most recent monograph Is Democracy Possible Here?, he has now turned his attention to the fraught state of American democracy. Indeed, while his attention has been on defending the liberal faith in illiberal times, his claim in this book can be fairly applied to his whole scholarly oeuvre -- "I have been talking about democracy ... all along." "Yet, for all its eloquence and power, his talk about democracy and his assessment of its present condition is decidedly schizophrenic. While he condemns present democratic arrangements as amounting to a "degraded politics [which] are not only insulting and depressing; they are not even democratic" (147), he commits himself to the foundational belief that "Americans of goodwill, intelligence, and ambition have given the world, over the last two centuries, much of what is best in it now" (163). It is Dworkin's enormous self-imposed task to reverse this 'degraded politics' and make good on the best that American democracy has to offer. In short, Dworkin's reflections and exhortations capture much of the anxious engagement in political debate generally -- the beacon on the hill may be faint and fading, but it still retains the capability to ignite and fulfill its traditional emancipatory mission.

In this essay, we want to examine the extent to which Dworkin's liberal project can provide the basis and impetus for such a democratic revival. Rejecting such a likelihood, we canvass some of the familiar topics that one might expect in a book titled Is Democracy Possible Here?, but which Dworkin ignores -- the limits of democracy in large societies, the maximization of popular participation, the problems or virtues of representation, and the meaning of the idea of popular sovereignty. To do this, the essay is divided into three main sections. In the first section, we first locate the broader constitutional and institutional contexts within which debates about the importance and salience of democratic politics have taken place and then we introduce Dworkin's distinctive and defiant contribution to that debate. In the second and main section, we offer a

${ }^{1}$ R. DWORKIN, IS DEMOCRACY POSSIBLE HERE? PRINCIPLES FOR A NEW POLITICAL DEBATE 155 (2006) (hereinafter all page references are in parenthesis in the text). 
substantial critique of Dworkin's proposals and demonstrate how his (and fellow constitutionalists') liberal project may be as much a part of the problem as the solution. That critique is divided into four parts; it includes a series of philosophical, political, constitutional, and historical arguments against the democratic credentials of Dworkin's project. The third section explores a different approach to how democracy can be more effectively and fully mobilized to meet the challenges of the contemporary world; the emphasis here is on more affirmative and constructive proposals. By way of conclusion, we speculate on the directions that further efforts might take to fulfil the promise of democratic politics in contemporary constitutional societies.

For us, in contrast to Dworkin and other liberal constitutionalists, whether 'democracy is possible here' depends on what counts as democracy, what possibilities it is thought to offer, and what weight it is given in political debate. $^{2}$ We maintain that, if democracy is to be realisable, then it needs to be of a more robust and less derivative kind than Dworkin's liberalism envisages. However, we are not arguing that any remnants of constitutionalism should be abandoned. Instead, we propose to re-dress as we challenge the supposed balance between constitutionalism and democracy and, in its place, combine a strong democracy with a weak constitutionalism. While Dworkin's invitation to "reinvigorate the argumentative dimension of our politics" (8) is to be warmly accepted, his own efforts result in more of a continuing affirmation of the present situation in which elite debate by way of constitutional interpretation passes for democratic engagement. Indeed, in contrast to many contemporary constitutional critics and jurists, we insist that it is more democracy, not less, that offers the best hope in moving forward in these troubled times.

\footnotetext{
${ }^{2}$ In talking about 'here', we recognise that some might think it odd that two Canadian academics -- one a joint British/Canadian citizen (who will be teaching in the United States next academic year) and the other an American citizen -- are analyzing the present condition and future of American law and politics. However, this is a strength, not a weakness. Our comments take Dworkin's work to be directed at most 'mature' democracies, especially Canada and the United Kingdom. Accordingly, the challenge that he outlines and our response to it are more general and less parochial. As Dworkin states, "I shall for the most part speak of these [shared] principles as the common property of Americans, but of course they are shared by a great many other people in the world" (7).
} 


\section{The Liberal Project}

\section{A. CONSTITUTIONALiSM AND DEMOCRACY}

Constitutionalism preceded democracy. The main elements of most states' constitutional orders were firmly in place before all persons were treated as citizens and before the franchise was extended to all those citizens. For instance, in the United States, although the fundamental constitutional compact was in place by 1787 , the final extension of the franchise did not take place until over 170 years later in 1964. Yet, even today, the percentage of voting-age population who actually vote in federal elections remains alarming low. From highs of mid- $60 \%$ s in the 1950 s and 60 s to present lows of around low $50 \%$ s for presidential election years; it is presently around mid to high $30 \%$ s for mid-term elections. However, despite the historical priority of constitutionalism and continuing low electoral participation, the growth of democracy as both an idea and practice has raised pressing concerns for political and legal theorists. In particular, while the constitutional order has developed and changed over time, the challenge of increased popular participation has obliged a reexamination of the appropriate and legitimate relationship between constitutionalism and democracy. ${ }^{3}$ The relationship between constitutionalism and democracy is clearly contested and complicated, but is it on its deepest and best understanding complementary or contradictory? Does the one reinforce and strengthen the other or is one the negation of the other? Can there be a mode of 'constitutional democracy' which is both coherent and reliable in effecting social justice?

The central notion of constitutionalism is that, although government is established to serve popular interests, popular government must be constrained in its powers if it is to retain authority in exercising those powers. As such, constitutions not only organise and distribute power, but they place limits upon its exercise. In its predominantly liberal incarnation, there is a strong belief that there must be procedural and substantive limits placed on what policies the citizens can require or expect their political

${ }^{3}$ See generally John Wallach, American Constitutionalism and Democratic Virtue, 15 RATIO JURIS 220 (2002). 
institutions to follow. Indeed, these constraints on contingent democratic demands can be seen as the foundational and enabling conditions for an enduring and virtuous democratic polity. In this vision, democracy is not the main process by which political justice is constituted or achieved, but is merely instrumental to the preservation and expression of that goal. There is, of course, much debate among constitutionalists about the nature and extent of these limitations. Some of the most common arrangements relied upon to achieve such a balance of power and accountability include the familiar notions of separation of powers, adherence to the rule of law, constitutional supremacy, and, of course, the protection of fundamental rights through judicial review. As John Rawls, the leading modern liberal constitutionalist put it, "in a constitutional regime with judicial review, public reason is the reason of its supreme court."

These basic features of modern constitutionalism have much to recommend them and have become accepted as the sine qua non of good governance. However, this is not the whole story. Constitutionalism is also characterized by an obsession with permanence, a resistance to constitutional change and a suspicion of constituent assemblies. Underlying many constitutionalist theories is the idea that, once the constitution contains the right abstract principles and the correct balance of institutional safeguards, it is a good and finished constitution. There is room for fine-tuning in the details of its operation and implementation as circumstances change, but there is no need or warrant for further changes of a substantial or structural kind. The claim is that to alter the constitution in important ways is to look for trouble, to play with the stability of a political system, and to risk the precious ideal of the rule of law. ${ }^{5}$

${ }^{4}$ JOHN RAWLS, POLITICAL LIBERALISM 231 (1993). See also B. ACKERMAN, WE THE PEOPLE, vols. 1 and 2 (1991 and 1998). For a more general appreciation of constitutionalism, see Richard Bellamy and Dario Castiglione, Constitutionalism and Democracy: Political Theory and the American Constitution, 27 BRITISH J. OF POL. SCI. 595 (1997); Stephen M. Griffin, Constitutionalism in the United States: From Theory to Politics, 10 OXFORD J. LEG. STUDIES 200 (1990); and Michel Rosenfeld, Modern Constitutionalism as Interplay Between Identity and Diversity in CONSTITUTIONALISM, IDENTITY, DIFFERENCE, AND LEGITIMACY (Michael Rosenfeld ed. 1994).

5 See, for example, MARK TUSHNET, TAKING THE CONSTITUTION AWAY FROM THE COURTS (1999). This foundational component of constitutionalism was 
Moreover, the rise of democracy and the spread popular entitlement has heightened those fears.

Democracy, of course, is one of the most uttered, yet least specified ideas in the political lexicon. It can and has been utilised by many different people in many different situations to defend or promote many different states of affairs. Indeed, its malleable and contested nature is a large part of its enduring political appeal. In the 1950s, it was reported that over 2000 years of political speculation had generated over 300 definitions of 'democracy'. ${ }^{6}$ This number has likely increased even further in the ensuing 50 years. Suffice it to say by way of introduction that the core of the democratic ideal is the preference for ordering power and authority in line with the views and requirements of the citizenry: the smaller that the gap is between the rulers and the ruled and between the powerful and the powerless, the better and more democratic that society will be. At its strongest, democracy is seen to be not only a formal process for tallying people's preferences, but also as a substantive vision of what the 'good life' should or could be. ${ }^{7}$ In regard to constitutionalism, the critical claim is that democracy is relegated to a distinctly second-best position. In particular, it is objected that the proposed limits on popular power are not and cannot be self-executing and must be interpreted by someone. Because there is no neutral or uncontested way to achieve that, the restraint on popular authority is illegitimate. Moreover, popular participation is not (or need not be) as unprincipled, arbitrary or self-serving as many

exemplified in late $18^{\text {th }}$ and early $19^{\text {th }}$ century France. The claim was that, as the Revolution had done away with injustices, there was little more to do. As Napoleon noted, "Citizens, the revolution is determined by the principles that began it. The constitution was founded on the sacred rights of property, equality, freedom. The revolution is over". See ANTONIO NEGRI, INSURGENCIES: CONSTITUENT POWER AND THE MODERN STATE (1999).

${ }^{6}$ See DEMOCRACY, IDEOLOGY AND OBJECTIVITY (A. Naess et al. eds. 1956).

7 See, for example, B. BARBER, STRONG DEMOCRACY: PARTICIPATORY POLITICS FOR A NEW AGE (1994). From a legal perspective, see JEREMY WALDRON, LAW AND DISAGREEMENT (1999) and JED RUBENFELD, FREEDOM AND TIME: A THEORY OF CONSTITUTIONAL SELF-GOVERNMENT (2001). 
constitutionalists suggest. At its most strident, therefore, the democratic critique of constitutionalism is that it operates more as a cover for elite control and facilitates a tyranny of that elite over the majority. In short, democracy and constitutionalism have very different attitudes and approaches to the wisdom and reliability of popular politics.

In line with this, the primary tension in legal and political theory is not between constitutionalism and democracy per se, but between different accounts of constitutionalism in terms of their willingness to place more or less confidence in popular politics in the pursuit of a democratic system of governance. In short, in a constitutional democracy and in contested matters of political morality, the central question is whether the prosaic or primary location of authority and legitimacy is to be found in the constitution or in the people? Traditional theorists have tended to view this question as primarily philosophical in scope and substance. However, we insist that, while the philosophical dimension is important, there are also equally important historical, political and strategic aspects which demand attention. Indeed, despite the frequently trumpeted value and importance of democracy in modern politics, its institutional imperatives and normative significance have been treated as decidedly inferior in the constitutional scheme of things: the chronological precedence of constitutionalism has been endowed with continuing conceptual priority by modern commentators and officials. Indeed, modern legal and political theory displays a discernible uneasiness towards the thrust and influence of democracy. And Dworkin, for all his apparent defence and promotion of democracy, is no exception.

\section{B. OF JURISTS AND EMPERORS}

Ronald Dworkin has been hard at work over the past forty years sculpting and polishing a political and legal philosophy of 'liberal legalism'. Spurred on by the prolific output of his arch-rival Richard Posner, he seems to have re-doubled his efforts in the last few years. Although he has never quite fully succeeded in wresting away the restricting grip of analytical positivism on modern jurisprudential scholarship, he has managed to develop a broad and sophisticated jurisprudence which holds to the implacable view that "law... is deeply and thoroughly political..., 
[b]ut not a matter of personal or partisan politics." ${ }^{\text {I }}$ In doing so, he has succeeded in putting issues of politics and morality squarely on the scholarly agenda of law and legal scholarship, particularly in the field of constitutional law. In becoming the chief proponent of a naturalist jurisprudence, he has also been the main and most energetic flag-carrier for progressive liberalism in contemporary American society.

His liberal positions on abortion, euthanasia, religion, and tax reform have found considerable, if reluctant, favour among the liberal and legal intelligentsia. ${ }^{9}$ Nevertheless, he has not managed to persuade many of his colleagues that his naturalist methodology -- the jurists' role is to offer "the best justification of legal practice as a whole""10 -- is the best route to go in defending such positions. His central jurisprudential claim that law as-it-is entails and embraces law as-it-should-be (particularly from a liberal standpoint) has met hostility from both liberal and non-liberal critics alike. As a legal scholar who seems to be contested and resisted in spite of his political views not because of them, Dworkin has wrought the philosophical and juristic structure for a version of legal liberalism which presents a formidable challenge to all those engaged in the fields of law and politics. He has become one of the bona fide "seers and prophets" that can legitimately lay claim to being willing "to work out law's ambitions for itself." ${ }^{\prime 1}$ It is an imperial and imperious undertaking. Is Democracy Possible Here? is a continuation and deepening of that liberal project with the emphasise very much upon its political as opposed to its jurisprudential dimensions -- "my main interest is in political principle, not law" (9).

${ }^{8}$ R. DWORKIN, A MATTER OF PRINCIPLE 146 (1985).

${ }^{9}$ See, for example, R. DWORKIN, LIFE'S DOMINION (1993), FREEDOM'S LAW: THE MORAL READING OF THE AMERICAN CONSTITUTION (1996), and SOVEREIGN VIRTUE (2001).

${ }^{10}$ R. DWORKIN, LAW'S EMPIRE 152 (1986).

${ }^{11}$ Id. at 407. 
In this latest monograph, Dworkin encourages citizens to engage in a genuine argument about their political disagreements. For him, this task is all the more pressing because the present state of American politics is "appalling" and "divisive" (1) . To overcome this debilitating malaise, Dworkin wants people to find some common ground through forging some basic principles on which they all can agree and then debate about which governmental policies might better reflect those shared principles. His self-imposed mission, therefore, is not only to identify what he thinks are the "shared principles of sufficient substance to make a national political debate possible and profitable" (6), but to examine some of the most controversial topics on the contemporary political agenda, such as terrorism, religion, and taxation, in light of them. This is an ambitious, timely, and laudable venture. Whatever else one might have to say about his performance, Dworkin cannot be faulted for his scholarly mettle. In grappling with the conundrums and conflicts of contemporary politics, he resembles nothing so much as the civic intellectual rather than the detached jurist.

Dworkin begins by outlining the principles which comprise "the common property of Americans" (7) and which might provide "the common ground that makes genuine argument among people of mutual respect possible and healing" (5). These are the principles of 'intrinsic value' and 'personal responsibility' and will come as no surprise to followers of Dworkin's writings. The first principle holds that human life has a "special kind of objective value" (9-10) and that it matters when a particular human life succeeds and when it fails. For Dworkin, to accept this principle is to appreciate the dignity of human life itself: "you cannot act in a way that denies the intrinsic importance of any human life without an insult to your own dignity" (16). On the other hand, the second principle holds that every human being has a "special responsibility for realizing the success of his own life" (10) and that includes deciding what a successful life is for him. For Dworkin, it is unacceptable that people subordinate themselves to the will of others in identifying value in their own lives. These two principles together "define the basis and conditions of human dignity" (10) and Dworkin refers to them as principles or dimensions of dignity. He then offers these two principles as having "sufficient substance" and as being "sufficiently deep and general so that they can supply common ground" for a political debate "about their interpretation and consequences for political institutions and practices" (11). 
Dworkin's extended argument about the substantive and institutional implications for American politics of such informing principles is, as expected, bracing and beneficial; his sophistication and range is truly impressive. However, as even more expected, he concludes that anyone who works from these principles and accepts them should reject certain policies currently defended by conservatives such as the existence of different legal procedures for citizens and foreigners suspected of being involved in terrorist acts, the teaching of intelligent design as a scientific alternative to Darwinian evolution, the prohibition of gay marriage, and the adoption of important tax cuts for the rich. There can be no doubt that Dworkin can safely assume that he will have succeeded in his main ambition -- "I said that I wanted to start an argument, and I have done my best" (160). Whether he will have managed to convince his political opponents is less likely and will have to be seen.

However, our brief is not to engage in a partisan or tendentious argument about the shared nature of his guiding principles or his liberal rendition of them; we are more concerned to examine the broader and deeper democratic implications of his philosophical analysis and political arguments. Nevertheless, that being said, although many of Dworkin's positions might chime with our own, a couple of critical observations are in order. First and more generally, it is difficult to see how his two principles of human dignity will be accepted as 'common ground' by his conservative adversaries. Despite Dworkin's insistence that "the principles are not in themselves political" (161), they seem to take a very individualistic and inherently liberal slant and leave little space for religious or other group commitments as many seem to demand and rely; it will be difficult for conservatives to frame their concerns in a way that is true to their own apparent operating assumptions. ${ }^{12}$ Second and more specifically, some of the concrete positions taken seem unclear or problematic. For instance, exactly why the death penalty is consistent with

12 See, for example, A. ETZIONI, RIGHTS AND THE COMMON GOOD: THE COMMUNITARIAN PERSPECTIVE (1995) and SAMUEL HUNTINGTON, WHO ARE WE?: THE CHALLENGES TO AMERICA'S NATIONAL IDENTITY (2004). See generally, JOHN MICKLETHWAIT AND ADRIAN WOOLDRIDGE, THE RIGHT NATION (2004). 
the principle of 'intrinsic value', particularly when torture and humiliation are considered as violations of it, is hard to appreciate. ${ }^{13}$

\section{Two VIEWS ON DEMOCRACY}

At the end of Is Democracy Possible Here?, Dworkin announces that "I have been talking about democracy in this book all along" (155). This follows quite naturally from his early works in which he has defended the jurisprudential position that a combination of constitutionalism and democracy is not only possible, but best exemplifies the special appeal of American politics and its historical practice. It will be remembered that Dworkin has devoted his career to the claim that it is not only appropriate, but necessary that the courts as a 'forum of principle' and, by way of constitutional review, serve as the final authority on contested matters of political morality. If judges do this properly, they will offer a moral reading of the constitution which will "elaborate a coherent constitutional morality." 14 This is not presented as a violation of democratic governance,

13 Also, Dworkin's line of argument about human rights seems to justify the U.S. invasion of Iraq. If a nation is justified in invading another only when the latter engages in violations of baseline human rights, that is, "rights that forbid acts that could not be justified by any intelligible interpretation of the ideas that people's lives are of equal intrinsic value and that they have a personal responsibility for their own lives" (36), these rights include, naturally, the right not to be tortured. Under this view, no doubt the United States was justified in invading Iraq, as the right not to be tortured was arguably routinely violated there. Dworkin even seems to use the idea of a nation being justified in invading another as a test for determining when a practice constitutes a baseline violation, as he does in the case of the death penalty: "But the case that capital punishment violates human rights seems, as I said, at best inconclusive as a baseline matter. We can understand the opinion of those who think it does, but they would no doubt agree that it would be preposterous for other nations to invade Texas or Florida to stop the practice, even if they were powerful enough to succeed" (40).

14 Dworkin, FREEDOM'S LAW, supra, note 9 AT 40. See also Ronald Dworkin, Equality, Democracy, and the Constitution: We the People in Court, 28 ALTA. L. REV. 324 (1990). In R. DWORKIN, JUSTICES IN ROBES (2006), he offers a similar defence of democracy. He states that "partnership in self-government ...is structured and made possible by a moral constitution guaranteeing to individuals one by one the prerequisites of full membership.... [and that] we are committed by our history to an institutional strategy of asking judges -- men and women trained in law -- to enforce those guarantees of equal citizenship." Id. at 139. 
but as a realisation of the very highest ambitions of democracy. Indeed, it is the main burden of this recent publication to develop and justify further the substantive conception of democracy that he has relied on to date.

In Is Democracy Possible Here?, Dworkin presents the two fundamental principles of human dignity as the source of 'partnership democracy'. This is his favored interpretation of the democratic ideal and he distinguishes it from a strictly procedural conception which he labels 'majoritarian democracy'. The majoritarian view maintains that democracy is simply government in accordance with the will of the greatest number of people as expressed in the election of officials (131). On this understanding, the policies adopted by a legislative assembly can be characterized as democratic because they are favored by a majority of the electorate. But this view does not hold that the majority is always right or that its decisions will always be fair. On the contrary, a majority may make very wrong or unjust decisions, but that is not relevant for characterizing those decisions as democratic. For Dworkin's majoritarian, the question of democracy is exhausted in the procedure by which a decision is taken: substantive content is eclipsed by procedural source. As such, the majoritarian view of democracy "allows us to say...that a decision is democratic even if it is very unjust" (134) and, therefore, presents itself as purely procedural ideal, independent of other dimensions of political morality.

According to Dworkin, the obvious problem with this conception is that it cannot explain what is good about democracy because it incorrectly assumes that the sheer weight of popular numbers contributes something of special value to a political decision (143). In this respect, Dworkin claims that some of the traditional arguments in favor of majority rule (e.g., that majority rule results in wiser and better government and that it is the only fair method of decision making) are mistaken. He maintains that there is no reason, historical or philosophical, to think that a majority is any more likely to reach the right answer about moral issues than a minority. Moreover, he contests the claim that majority rule is fair because it gives each citizen equal political power: representative government gives much more power over political decisions to people who hold office than people who do not. For Dworkin, therefore, the partnership view of democracy qualifies the relationship between majority rule and democracy. For him, democracy does not mean that the majority should 
always or even most of the time have the final word: all that democracy requires is that the people govern themselves by treating each individual as a full partner in a collective enterprise (131). Consequently, in Dworkin's partnership version of democracy, decisions are democratic only when the conditions that protect the status and interests of each individual as a full partner are met. Thus, when a community decides by majority rule (or by unanimity for that matter), to ignore the interests of some individual or group, its decision will not simply be unjust and open to rebuke: it will have nothing to do with democracy.

Unlike the majoritarian view of democracy, partnership democracy not only has substantive implications, but it is defended by Dworkin precisely because "democracy is a substantive, not a merely procedural , ideal" (134). The merit of a particular law or policy and, therefore, its potential to improve democracy is not assessed by considering the procedure by which tit came into being; its substantive cut and content must be consistent with and preferably capable of advancing the "theory of equal partnership" (134). If that theory allows for such content, then the law or policy has democratic credentials whether it would have arisen from majoritarian politics or not. In Dworkin's approach, therefore, the true test of democratic merit is in no way connected to its institutional source or procedural pedigree, but is exclusively controlled by whether it can be made to square with the philosophical demands of the two foundational principles of human dignity.

Nevertheless, Dworkin does consider that the partnership view of democracy has procedural implications. When there are disagreements about what law or policy is more consistent with a democratic ideal, there must be a reliable procedure in place for reaching collective decisions. Not surprisingly, as with the substantive implications of partnership democracy, these procedures must follow from the same principles of intrinsic value and personal responsibility. From the former, it can be deduced that a community must show equal concern for the human beings that live within its borders. According to Dworkin, this is best achieved with widespread and roughly equal suffrage because "officials elected by a broad swath of the population will do a much better job of protecting the weak against special privilege and tyranny than officials elected by and responsible to only a few" (144): the test of whether a constitutional arrangement shows genuine procedural equality is to inquire "whether that 
arrangement is likely to produce policies that respect substantive equality in concern for people's lives" (145).

Similarly, from the second principle of human dignity, Dworkin concludes that it follows that political arrangements must respect the personal responsibility of individuals. This is taken to imply that a contingent majority has no automatic right to impose its will over other human beings, even if the majority's laws and policies are designed in a way that further their overall interests. Consequently, the second principle of human dignity is considered to require that the basic procedure utilised to reach and validate collective decisions be compatible with the principle of selfgovernment. Although it might compromise a person's dignity to submit to the decisions of others, such dignity is not compromised when that person does take part, as an equal partner, in those decisions (145). The upshot of this is that Dworkin understands the institutional implications of self-government primarily in terms of the protection of certain individual rights. While all persons must be able to participate in collective decisions, there are certain aspects of each participant's life that must not be susceptible to interference by such collective decisions. In this respect, therefore, the usual slate of fundamental rights must be guaranteed, including the right to participate in collective decisions as both voter and candidate for office; this will ensure that the majority will not impose its will in deciding whether and how religion or other ethical values will play a part in an individual's life.

By way of conclusion, Dworkin argues that his account of partnership democracy, unlike the majoritarian one, fits very well the structure of the American constitution and presents it in its very best light. As he states, "the list of constitutional rights in the United States Constitution, as these have been interpreted by American courts over recent decades, does a reasonably good job of identifying and protecting the political rights that flow from the two principles of dignity and converting those political rights into legal rights" (32). Of course, that does not mean the United States is a paragon of partnership democracy, even if its basic structure approximates to its procedural ideal. As Dworkin shows throughout Is Democracy Possible Here?, some of the concrete policies adopted by its legislature violate the substantive requirements of the principle of intrinsic value and the principle of personal responsibility. Nevertheless, Dworkin makes a resounding case for why the general structure and practices of 
American constitutional politics are so desirable and definitive: exceptional lapses from democratic grace merely serve to prove the general rule of constitutionalist integrity.

\section{The Democratic CRITIQUE}

In crafting and defending his account in Is Democracy Possible Here?, Dworkin has left no doubt that not only are constitutionalism and democracy compatible, but that his vision of liberal constitutionalism is the best available. Indeed, he is clear that democratic politics are an inferior mode of constitutional politics because it is important to put many matters of political morality outside the reach of popular political debate and disagreement. For him, it is simply axiomatic that "[judiciallyenforced] constitutional rights ... are not compromises of democracy, but rather attempts to guarantee it" (146). Consequently, insofar we maintain that this is a mistaken and unnecessary conclusion, we must demonstrate why that is so. In the critique that follows, we mount a four-pronged rejection of Dworkin's position and proposals:

1. the philosophical argument relies on a dubious objectivist epistemology which is ill-suited to his larger democratic project;

2. the political argument offers a very limited role for popular participation in the governmental scheme of things;

3. the constitutional argument does not take seriously the importance of openness and revisability in a democratic culture; and

4. the historical argument over-estimates the success of constitutions and courts as the best protectors and promoters of liberal justice.

Throughout this section, we will insist that democratic politics need not be muted and marginalised in the struggle to achieve social justice and political virtue. On closer inspection, Dworkin's distinction between the partnership and majoritarian views of democracy is highly suspect and unconvincing; it represents an unwarranted domestication and trivialization of the democratic ideal and its transformative possibilities. If democracy is truly limited in accordance with Dworkin's account, it is not surprising that many citizens and commentators might abandon and even 
renounce democracy as a regulative theory and practice. However, democracy is far from exhausted or best showcased by the limited possibilities of Dworkin's partnership and majoritarian accounts. To reject Dworkin's favoured 'partnership democracy' is not to embrace the impoverished and caricatured vision of majoritarian democracy that Dworkin portrays: democracy is a much richer and ample idea and practice than that.

\section{A. A Philosophical Mistake}

Dworkin talks a good deal about the search for "the common ground that makes genuine argument among people of mutual respect possible and healing"(5) as a way of stabilizing and moving forward his political agenda. It is intended to be a conciliatory and inclusive gesture which will establish his democratic bona fides. However, there should be no mistake that this search is less a political endeavour than a philosophical undertaking. He insists that "there is an objective standard of success in living" (13). By this and in line with his earlier work, Dworkin means to insist that there is some objective ground or moral facts-of-the-matter which must necessarily underpin this foundational effort to find common ground. Indeed, when it gets down to it, Dworkin does not seem very interested in collaborating with his fellow citizens in order to build some basic and shared philosophical principles to support the political engagement. Instead, he is involved in the more familiar, yet less collegial assignment of unearthing some given set of informing principles. In so doing, he gets his project off on entirely the wrong foot by betraying the supposedly democratic foundations of his philosophical and political constructions.

Despite appearances to the contrary, Dworkin offers a standard objectivist account of political morality. As a committed conceptualist, he takes social practices (i.e., law, morals, etc.) and subjects them to a logical and abstract inquiry in order to determine and illuminate their essential features. In a revealing passage about the epistemological nature of his political inquiry in Is Democracy Possible Here?, he states that "there is objective truth to be had in the realms of ethics and morality ... because the opposite, skeptical claim is philosophically indefensible ... and rejecting that skepticism is part of the common ground we share" (46). These are 
not a merely throw-away lines for Dworkin; they go to the heart of his continuing intellectual project. He maintains that it is not a philosophical mistake to talk about values as being true or false. For him, values are real in that their existence or character are not reducible to anyone's beliefs or preferences. While he admits that this stance is controversial, he nevertheless continues to promote and defend it. Indeed, he has recently gone so far as to state that:

just as a scientist can aim, as a distinct kind of project, to reveal the very nature of a tiger or of gold by exposing the basic physical structure of these entities, so a political philosopher can aim to reveal the very nature of freedom by exposing its normative source. In each case we can describe the enterprise, if we wish, as conceptual. The physicist helps us to see the essence of water; the philosopher helps us to see the essence of liberty. ${ }^{15}$

In pursuing this conceptual and essentialist goal, Dworkin maintains that reflective height is the guarantor of moral depth. In resolving difficult and contested issues of political morality, he reminds judges that "the ladder of theoretical ascent is always there, on the cards, even when no one is tempted to take even the first step up it" and that "we cannot pursue that indispensable ambition [of living together as equals] unless we undertake, when necessary, to ascend high enough in our collective deliberations, including our adjudicative deliberations, to test our progress in [ensuring that the principles under which we are governed treat us as equals]."16 Insofar as he expects judges to make an occasional 'justificatory ascent' in order to ensure that substantive or local justice on any particular issue is not achieved at the price of formal inconsistency with the law's own overarching principles, Dworkin would surely expect at least as much and perhaps more from his philosophical interlocutors. Accordingly, although he frames his initial inquiry in the inclusive terms of searching for

${ }^{15}$ JUSTICE IN ROBES, supra, note 14 at 155 . Dworkin will be publishing still another new book this year, titled Justice for Hedgehogs, which will further advance and defend this objectivist epistemology.

${ }^{16}$ Id. at 56 and 74. 
common ground and shared principles, he also insinuates that there are some objective facts-of-the-matter which can be found and that, once found, should discipline future debate and disagreement. These exhortations to turn all problems into philosophical ones and to demand a particular philosophical resolution of them are of the most dubious provenance. With these broad flourishes, he exposes the contrivance of his gesture to look for shared principles and, instead, dismisses not only anyone who disagrees with that, but also any serious attempt to remain true to a democratic spirit of inquiry and debate. Indeed, there is little room for debate when confronted with 'facts'; they demand only acknowledgment or denial.

On a more rigorous democratic approach, there is no need to accept this very particular and frankly elitist characterization of the philosophical enterprise. It is simply wrong to posit that the only alternative to an objectivist philosophy is a skeptical stance which contends that "our opinions about how to live are not reports of objective fact but just projections of our deepest emotions" (13). This is simply not the case and does scant credit to the American philosophical tradition. ${ }^{17}$ Dworkin caricatures the skeptical position, particularly in regard to opinion being "just projections of our deepest emotions" (13). But, as he concedes, these skeptics still continue to "suppose that there is a better and worse way for them to live and that it is important to live in the better way" (13) and that they believe that "we can make mistakes about what it is to live well, and these mistakes are matters for very great regret" (14). To take that stance is not to subscribe to Dworkin's objectivist view and nor is it a matter of emotional projection. The possibilities are much richer than in Dworkin's limited and monochromatic epistemological world.

Moral clarity or progress is not about ascending to some higher, more removed and abstract plane on which rationality can hold sway outside of the disabling influence of interests, commitments, fuzziness, history, culture and ideology; it is about closing the gap between aspirations and

${ }^{17}$ Dworkin's marked tendency to posit stark and unrealistic dichotomies is typical of his overall rhetorical approach. As with his representation of democracy, he skews the whole analysis by obliging critics to make a Hobson's choice between two entirely limited and loaded options. See supra pp. 11-14. 
actuality, about making the world a better place. There is simply no need to posit the existence of objective moral facts which can be discovered by seeking some ahistorical detachment or justificatory height. Philosophers like Dworkin cannot seem to accept that justification is not about the abstract or special relation between ideas, but is a social practice that has or requires an external authority to its own contextual development. Indeed, it is far more preferable to abandon the conceit that it is only possible to be "theoretical" if one escapes the bounds of "cultural and social" context and seeks to transcend "traditions and genres" as Dworkin does. ${ }^{18}$ So often, this manoeuvre simply operates as an elaborate ploy to endow personal preference with the trappings of objective truth.

In line with a democratic commitment, it is better to work from the premise that, when it comes to morality, there is no fact-of-the-matter which is independent of argument and debate; the grounds of political morality are within the debate, not outside or regulative of that debate. Echoing John Dewey and other pragmatists, Hilary Putnam is persuasive that "ethical talk needs no metaphysical story to support it ...; it only needs what ethical talk ... has always needed: good will, intelligence, and respect for what can be seen as grounds and difficulties from within the ethical standpoint." 19 This ethical talk is by its nature social and contextual. It is social in that it amounts to more than the idiosyncratic or private 'emotional projections' of particular individuals. And it is contextual in that it is always located in social settings, but never entirely overwhelmed by them. Consequently, "the standard of success in living" (13) is neither objective nor subjective as Dworkin is wont to suggest. Being collaborative and contextual is entirely complementary to and compatible with a democratic appreciation of politics and political debate.

\footnotetext{
${ }^{18}$ Dworkin, Objectivity and Truth: You'd Better Believe It, 25 PHIL. \& PUB. AFFS. 87 at 133-34 (1996). For a more extensive critique of that position, see Hutchinson, Casaubon's Ghosts: The Haunting of Legal Scholarship, 21 Legal Studies 66 (2001).

19 HILARY PUTNAM, THE COLLAPSE OF THE FACT/VALUE DICHOTOMY 9495 (2002). See also J. DEWEY, EXPERIENCE AND NATURE 407-08 (2d ed. 1958); R. RORTY, PHILOSOPHY AND SOCIAL HOPE 266 (1999); and Hilary Putnam, A Reconsideration of Deweyan Democracy, 63 S. CAL. L. REV. 1671 (1990).
} 
Ironically, Dworkin begins his own philosophical quest in exactly the place that democratic pragmatists would recommend -- the search for a "common ground to be found between the trenches of ... hostile political armies" (6). This is a laudable project that is not only important for democracy, but that goes about it in a way that is democratic in form and ambition. The project itself is exactly what skeptics approve of and recommend. It is not about confronting people with 'objective facts' which they have little choice other than to acknowledge: it is about working with the available conversational resources, engaging with others, and seeking to build, not impose, a common set of assumptions and shared values through "real argument" (6). Sadly, Dworkin fails to sustain this democratic project and, instead, reverts to objectivist type. Although he protests that "no nation's politics can be run like a philosophy seminar; a democracy must give the final verdict on who leads it to many millions" (127), almost all of Is Democracy Possible Here? is given over to exactly that; it is an objectivist lesson in moral fact-finding in which the professor speaks and the citizens listen. This is a far cry from a democratic exercise.

\section{B. A Political SQueeze-Out}

Nothing has come easy to the democrat; the history of democracy is a tale of resistance and courage. There is no reason to think that it is any different today. If people are to take an active part in governance at all levels of the community, there has to be a constant struggle to advance the project of 'closing the gap' between governed and governors by way of 'popular participation'. On this strong account, democracy is not exhausted in watching others decide what is best for the people; democracy is a mode of government by the community as well as for it. However, these ideals of democracy have often been belied and occasionally betrayed by their practical realisation. Beginning in 6th Century B.C. Greece, there was less a democracy and more a timocracy in which wealth and land ownership (not to mention, being male and unenslaved) were a condition of the voting franchise. Indeed, a skeptical review of democracy's history suggests that there is almost a disturbing 'inverse correlation' between the extension of the franchise and a reduction in the amount of power in which the enfranchised can participate: the more that people are allowed to participate as an electorate, the less that is left to their decision-making authority. Nevertheless, a 
persistent rallying-cry of democrats has been the need to involve people as fully as possible in all those institutions and agencies which influence and affect their daily lives.

However, for all the political hoopla and hollering in support of democracy and its political significance, there has been a distinct distrust of ordinary citizens' capacity to participate fully, freely, frequently and actively in their own governance. In the twentieth century, democracy came to be associated almost exclusively with the institutional and competitive struggle for people's votes by those leaders who sought political power. Accommodating prescriptive ideals to descriptive realities, commentators and politicians reduced popular participation to little more than the demand for free and fair elections among multiple political parties in a context of relatively open information: "democracy is government by officials who are accountable and removable by the majority of people in a jurisdiction." 20 Along with the judicially-enforced protection of basic civil rights, this constrained idea of democracy has come to dominate and is the accepted gold standard of democratic legitimacy for almost all contemporary regimes; the goal of a more extensive popular participation seems to have fallen by the wayside. ${ }^{21}$ Yet this radical separation between the rulers and ruled is a very far cry from what democracy meant just a few centuries ago, even to its opponents. By and large, democrats have been thwarted in their efforts to institutionalize

${ }^{20}$ JOSEPH NYE, THE PARADOX OF AMERICAN POWER: WHY THE WORLD'S ONLY SUPERPOWER CAN'T GO IT ALONE 109 (2002). This exemplifies the dominant tradition in political theory. See J.A. SCHUMPETER, CAPITALISM, SOCIALISM AND DEMOCRACY (1947); ROBERT A. DAHL, A PREFACE TO DEMOCRATIC THEORY: HOW DOES POPULAR SOVEREIGNTY FUNCTION IN AMERICA? (1956); ANTHONY DOWNS, AN ECONOMIC THEORY OF DEMOCRACY (1957); and HARRY ECKSTEIN, A THEORY OF STABLE DEMOCRACY (1961).

${ }^{21}$ There is a sub-field of scholarly endeavour which attempts to measure democracy by establishing objective indicators that measure Dahl's contestative and participatory dimensions of democracy. See, for example, DEMOCRACY AND DEVELOPMENT: POLITICAL INSTITUTIONS AND WELL-BEING IN THE WORLD, 1950-1990 (A. Przeworski et al. eds 2000) and David Beetham, Towards a Universal Framework for Democracy Assessment, 11(2) DEMOCRATIZATION 1 (2004). 
the belief that the governed are not only competent to elect their governors, but also entitled to make political judgments for themselves about all, not only some substantive issues. Indeed, democracy has almost become a form of government that most 18th century anti-democrats would be willing to support.

Dworkin's view of the role and place of democracy in constitutional governance fits snugly in this received tradition. Both of his 'majoritarian' and 'partnership' accounts are satisfied and fulfilled by the election of officials every few years. The only fundamental difference is that his favoured partnership account qualifies and limits the nature of the laws and policies that those officials might adopt. Whereas majoritarian democracy is merely the election of officials every few years, partnership democracy is the election of good officials every few years (i.e., officials that only adopt laws and policies that are compatible with Dworkin's shared principles of human dignity). Participation is not something to be valued in and of itself. This explains why Dworkin emphasises the importance of introducing changes in the public education system and in election law which will directly strengthen the quality of political argument (147). By receiving a public education which includes the discussion of topical controversies, citizens will be better prepared to make informed decisions about the selection of officials (148). Moreover, various reforms -- modifying election law so as to require the existence of special public broadcasting channels to offer continuous election coverage during each presidential election, limiting overall radio and television expenditures for all candidates, and establishing a 'right to comment' whereby all major cable networks must set aside a slot for each principal political parties to correct what they understand as error or bias in that network's reporting -- will result in a more engaged electorate (150-52). ${ }^{22}$

There can be little doubt that such innovations are to be welcomed and will likely enhance the popular political culture and facilitate electoral participation. Nevertheless, they remain limited in focus and ambition; they will do little more than improve the sort of spectator or consumer democracy which underlies both of Dworkin's majoritarian and

${ }^{22}$ These ideas build on Dworkin's earlier efforts to negotiate the tension between constitutionalism and democracy. See FREEDOM'S LAW, supra, note 9 at 15-20. 
partnership views of democracy. These narrow conceptions of democracy reduce politics and popular participation to a system in which people are expected to select among candidates for office as if they were products marketed and sold to them by the major political parties. Political life begins to mimic commercial enterprise; electoral politics is reduced to a hollow spectacle in which form triumphs over substance. ${ }^{23}$ Indeed, it is exactly this limited and limiting depiction of political engagement and popular participation that helps to bring about the "appalling" and "divisive"(1) state of contemporary politics that Dworkin so rightly deplores. A such, his proposals do as much to perpetuate and entrench the problem as remedy and improve it. Whereas majoritarian democracy permits people to choose among products through the right procedures, partnership democracy only permits them to choose good products. The changes in education and election law that Dworkin suggests appear then as the 'Consumer Reports' of democratic politics, helping people to distinguish between good and bad candidates or, more accurately, between those candidates who do and do not favor policies that are consistent with Dworkin's principles of human dignity.

Because Dworkin's conception of popular participation amounts to little more than "voting and holding office" (48), there is simply no possibility to take seriously a more active and extensive practice of popular participation. Neither of his democratic conceptions seeks to create institutions that maximize the participation of citizens in the continuing processes by which legal and regulatory policies are debated and enacted. This ought not to come as a surprise because, under Dworkin's vision of those substantive principles of human dignity which should animate democracy, an increase in and deepening of popular participation might actually hurt rather than improve democracy. For instance, according to Dworkin, a system that maximizes the greatest involvement by ordinary citizens in deliberation and decision-making in a variety of settings and by a variety of devices might well be less democratic than the United States today if that system produces the 'wrong decisions'. On the other hand, a system that leaves those decisions in the hands of an unelected group of officials might well constitute an exemplary democracy as long as the

${ }^{23}$ See A. HUTCHINSON, WAITING FOR CORAF: A CRITIQUE OF LAW AND RIGHTS 198-206 (1995). 
right decisions are produced. As such, it is clear that both Dworkin's conceptions of democracy potentially deprive the political system of the participation of citizens in the adoption of the rules that govern their lives.

Democracy cannot merely require, as Dworkin suggests, a system that gives "the final verdict on who leads it to many millions of people" (127, emphasis added). This is to put popular participation squarely and perversely in the service of oligarchy, not democracy. Moreover, even Dworkin's defence of the right to vote is dubious in democratic terms because it tends to reduce it to only consequential and symbolic value. For Dworkin, voting in regular elections is important because it is the best way of ensuring that government officials act with equal concern for all the human beings within the state's boundaries rather than with special concern for only a segment of the population (144). Accordingly, even voting, which is an essential, but small part of what the ideal of popular participation entails, is not fundamental in itself; it is important only insofar as it advances the more fundamental principle of 'equal concern'. This means that, if it was more defensible or prudent to rely on another mechanism to guarantee that officials treated citizens with equal concern, even voting as the remaining avenue for popular participation would be dispensable. Dworkin anticipates that allegation, but, in doing so, only manages to confirm that voting's importance is more symbolic than anything else. For Dworkin, depriving a citizen of equal vote would show a lack of concern and would constitute "the most blatant and symbolically outrageous possible violation of the democratic conception of human dignity" (145). Participation in the election of officials is welcomed and defended, but only as an adjunct to advancing his vision of liberal constitutionalism.

In marginalizing popular participation, Dworkin is in good company. However, those who adopted a similar strategy of containment considered themselves to be the opponents of democracy, not its champions. In particular, the post-revolutionary theorists of the eighteenth century recognised the subversive potential of popular participation: that is why they opposed it. For them, popular participation was by its very nature problematic as it entailed sharing decision-making and granting political 
power to the lower classes of society. ${ }^{24}$ Of course, the Federalists were also in this group and gave clear voice to their fears. As part of his general aversion to the 'tyranny of the majority', James Madison himself warned that "[pure] democracies have ever been spectacles of turbulence and contention; have ever been found incompatible with personal security, or the rights of property; and have in general been as short in their lives, as they have been violent in their deaths." ${ }^{, 25}$ Not surprisingly, Madison's did not evince much anxiety about an executive or minority tyranny, but contented himself with resisting universal suffrage as it would drive a wedge between public opinion and private property. Like Dworkin, the Federalists not only understood democracy as warranting popular participation in government, but offered 'representative democracy' as a more manageable and less disruptive alternative: they did not defend representation as a response to the practical reality of a large federal republic, but recommended a large federation in order to make representative, as opposed to direct, democracy necessary. Madison favoured representative government precisely because it would work as a bulwark against popular participation: "the larger the republic the better, since the ratio of representatives to represented would thereby be reduced. ${ }^{26}$ This is to embrace popular participation only so as to smother it better.

Consequently, even if it requires some trade-offs and compromises to be put into practice in large societies, democracy is a regime of popular selfgovernment which not only allows for, but relies upon participation by citizens in the formulation and enactment of the laws that govern their

${ }^{24}$ See Claude Ake, Dangerous Liaisons: The Interface of Globalization and Democracy in DEMOCRACY'S VICTORY AND CRISIS 282 (Alex Hadenius ed.1997); Sheldon Wolin, Fugitive Democracy in DEMOCRACY AND DIFFERENCE: CONTESTING THE BOUNDARIES OF THE POLITICAL 37 (Seyla Benhabib ed. 1996); and Ellen Meiksins Wood, Democracy: An Idea of Ambiguous Ancestry in ATHENIAN POLITICAL THOUGHT AND THE RECONSTRUCTION OF AMERICAN DEMOCRACY (J. Peter Euben et al eds.1994).

${ }^{25}$ THE FEDERALIST 61 (no. 10) (Jacob Cooke ed. 1961).

${ }^{26}$ Id. at 283. 
lives. At its most general, it is the rule of everyone by everyone. ${ }^{27}$ However, the fact that the contemporary institutions and arrangements considered 'democratic' are far from the most participatory forms of political organization that might exist is not considered a weakness or failing by Dworkin and other faux-democrats. Indeed, they are presented as the very kinds of institutions and arrangements that democrats should defend: the perverse position appears to have been reached in which popular participation is dispensable and no longer treated as an essential part of what is considered to be 'democratic'. Under liberal constitutionalism, democracy is exhausted by a constitution that establishes representative government, protects liberal rights, and enables all citizens to 'participate' in government by the election of officials. This is an impoverished and disabling idea of democracy and one which has little place for the emancipatory potential of popular participation and democratic openness. But it is also the democracy of constitutional democracy and, more pertinently, of Ronald Dworkin.

\section{A Constitutional Confusion}

Democrats are especially preoccupied with sources. No matter how fair a legal principle or rule seems to be, a democrat will always be interested in questions about its origin and, therefore, its legitimacy. In particular, the whos and hows of any established principle or enacted rule will be of compelling interest. A vital and principled dimension of any just law is the fact that it originated in an exercise of self-legislation by the governed, not simply be imposed or made on their behalf: democracy is about rule by the people and not only for the people. ${ }^{28}$ However, the democratic pedigree of

27 MICHAEL HARDT AND ANTONIO NEGRI, MULTITUDE: WAR AND DEMOCRACY IN THE AGE OF EMPIRE 240 (2004).

${ }^{28}$ A number of jurists have been giving some thought to what it takes for a body of law to be regarded as the law of the people to whom it applies, not only in traditional the sense of them being its subjects, but in the stronger sense that the law is theirs, something that they made. See Frank Michelman, Constitutional Authorship in CONSTITUTIONALISM: PHILOSOPHICAL FOUNDATIONS 76 (Larry Alexander ed. 1998); FRANK MICHELMAN, BRENNAN AND DEMOCRACY (1999); Waldron, supra, note 7 at ch.3; and Jeremy Waldron, Can there be a Democratic Jurisprudence? (unpublished paper, April 2004). 
a law is not the only concern of a democrat: democratic lineage is a necessary, if not always sufficient condition for an initiative's just quality. Both the matter and manner of laws are important. Indeed, it is the procedural mode of their creation that bolsters and underwrites the substantive merit of those laws; matter and manner are intimately related and re-enforcing. While this attention to sources has considerable salience in the legislative arena, its implications are even more pressing in regard to constitutional or fundamental laws which, by their nature, are often beyond the reach of day-to-day politics. Accordingly, the amenability of such constitutional arrangements and fundamental laws to periodic reconsideration and revision seems an indispensable part of any democratic compact. While our earlier political objection concerned the nature of present democratic arrangements, our constitutional criticism focuses on the past and future of democratic governance.

For constitutional democrats, like Dworkin, the equal attention paid to procedural means in relation to substantive ends is unacceptable because they consider that it is the 'rightness' of the decision that trumps all other concerns. Dworkin is firm on this. In his version of a substantive conception of democracy, he welcomes and defends the permanent institutionalization of what are taken to be the right abstract principles which people, if truly rational, would have chosen anyway. The legislative policies adopted by a representative assembly must accept the intrinsic value of human life and respect the capacity of each individual in deciding what counts as a successful life if they are to be considered democratic. His partnership view of democracy fuses together substance and procedure because it asks that policies are not only adopted 'democratically', but that they are just and, therefore, compatible with the shared principles of dignity. This is why Dworkin says that the partnership view of democracy "fits the basic structure of our own political system very well" (146) and that the Constitution, as interpreted by courts over recent decades, "does a reasonably good job of identifying and protecting the political rights that flow from the two principles of dignity and converting those political rights into legal rights" (32).

For Dworkin, if the results of popular participation do not do not chime with his preferred liberal vision of human dignity, they are unacceptable and, in constitutional terms, should be rejected. This places tremendous weight on the democratic legitimacy of existing constitutional 
arrangements. In particular, it obliges serious scrutiny to be given to the relation of democracy to the people and their constitution -- how did the constitution came into effect (e.g., is the constitution the result of a democratic process?) and how can it be altered (e.g., can the constitution be altered through democratic means?). ${ }^{29}$ However, neither of Dworkin's alternative views of democracy addresses the democratic quality of constitutional arrangements or fundamental laws. Whereas the majoritarian view is perfectly compatible with a constitution adopted from the top-down and containing stringent limitations on popular participation even in times of constitutional change, the partnership conception of democracy sets the traditional content of a liberal constitution as its procedural pre-condition and renders the issue of popular participation in possible constitutional change as simply irrelevant. By presenting the content of a liberal constitution as the procedural implications of the two 'principles of human dignity', Dworkin moves the fundamental provisions of the constitutional text outside the reach of democratic politics: "we may better protect equal concern by embedding certain individual rights in a constitution that is to be interpreted by judges rather than by elected representatives, and then providing that the constitution can be amended only by supermajorities" (144).

${ }^{29}$ One scholar who has explored how constitutions are ordained by "majority-rule popular sovereignty" and whether that can be done (lawfully) again is Akhil Reed Amar. See Akhil Reed Amar, Popular Sovereignty and Constitutional Amendment in RESPONDING TO IMPERFECTION: THEORY AND PRACTICE OF CONSTITUTIONAL AMENDMENT 109 (Sanford Levinson ed. 1995). His central argument is that the U.S. Constitution is a populist document that recognizes the legal right of the American electorate of altering their constitution in ways not contemplated in its amendment procedure. He maintains that the U.S. Congress would be obliged to call a constitutional convention if a majority of voters so decided and that amendments proposed by such a convention could be lawfully ratified by a simple majority of the electorate. For Amar, the procedure contemplated in Article V enumerates only the modes in which government (as opposed to the people) can change the constitution. See Akhil Reed Amar, The Consent of the Governed: Constitutional Amendment Outside Article V, 94 COLUMBIA L. REV. 457 (1994). While Amar's defense of popular sovereignty involves a radical rejection of the traditional principle of constitutional supremacy, he nevertheless seeks to legalize the democratic principle by looking for a place for popular sovereignty in a juridical arrangement and by locating the origin of the right to alter government in the constitutional text itself. However, in so doing, he fails to recognize the political character of the conflict between constitutionalism and democracy. 
Yet Dworkin is not finished. He goes on to argue that majorities should not be allowed, "whenever they wish, to change the basic constitutional structure that seems best calculated to ensure equal concern" (144). ${ }^{30}$ However, it is unclear why he allows for the possibility of constitutional change at all. If a constitution provides for the rights and procedures that make partnership democracy possible, as Dworkin insists the United States Constitution does, then there is little reason to be concerned at all with how it came into existence or whether it can ever be re-written. In light of this, Dworkin's protest that "no nation's politics can be run like a philosophy seminar" (127) seems particularly empty at the level of the fundamental laws. When the abstract principles of human dignity ground democracy, it is philosophy, not politics, that have fundamental priority in the constitutional scheme of things. Indeed, the whole point of Dworkin's philosophical enterprise is to insulate the foundational principles of liberal constitutionalism from democratic politics.

This antipathy to popular participation is embodied by existing approaches to constitutional reform. The motivating idea is that change should be infrequent because the stability of a juridical order is an primary value to be protected. However, constitutional democrats do concede that a large part of a liberal constitution's legitimacy rests in the fact that it can be changed through juridical means. Consequently, by way of compromise, liberal constitutions tend to make the process of amendment so arduous that few proposals for change are able to meet its stringent requirements. ${ }^{31}$

${ }^{30}$ In this, Dworkin follows John Rawls who stated that basic liberties must "no longer be regarded as appropriate subjects for political decision by majority or other plurality voting...They are part of the public charter of a constitutional regime and not a suitable topic for ongoing debate and legislation”. See Rawls, supra, note 4 at 151.

31 Also, these limits on constitutional reform extend well beyond basic liberties and include the entire structure of government. The amendment provisions of most modern constitutions underwrite the permanence of the constitutional order. See, for example, Article V of the U.S. Constitution. These provisions usually involve a set of requirements that are more difficult to meet than those followed when the constitution was originally adopted. While most constitutions are adopted by some form of majority rule, constitutional amendments are traditionally associated with super-majorities and other obstacles designed to decrease the possibility of important transformations. Some constitutions even place some clauses outside the scope of the amendment procedure, thus highlighting the fear of constitutional change that characterizes constitutionalism. See, for example, Article 79.3 of the German Basic Law. 
Moreover, the proto-typical liberal constitution does not include mechanisms which increase popular participation during times of important constitutional transformation. There is little reference to, for example, the election of delegates that deliberate in extra-ordinary assemblies whose proposals have to be ratified in referendums: democratic legitimacy is thought satisfied by the involvement and authority of ordinary representatives. ${ }^{32}$ This effort to regulate transformative shifts not only makes constitutional change difficult and infrequent, but also works to effect a permanent closure of the political. By making all political power subservient to the disciplinary protocols of the constitution and the rule of law, it no longer becomes reasonable to speak of important constitutional transformations except after cataclysmic events such as revolutions and coup d'états. Even after those events, it is thought that "by making a constitution, the revolutionary forces are digging their own graves.",33

For the democrat, a political system that has entrenched the 'right' abstract principles in what is thought to be a finished constitution and that has frozen in place a particular juridical arrangement sits uncomfortably with any genuine commitment to democracy. Democracy resists political closure; it fosters, not forecloses political and popular engagement. While a more democratic position is not indifferent to outcomes and is promoted on the basis that it will result in a more just society, its critical wager is that the governed will produce more outcomes which are more conducive to society as a whole than those dictated by abstract and partial principles or by elite institutions and agencies. It should be clear that the democratic critique is not about a conflict between rights and popular participation, but about the institutionalization of a juridical arrangement that, by

\footnotetext{
${ }^{32}$ See Steven Holmes and Cass Sunstein, The Politics of Constitutional Revision in Eastern Europe in RESPONDING TO IMPERFECTION: THEORY AND PRACTICE OF CONSTITUTIONAL AMENDMENT 277 (Sanford Levinson ed. 1995) and Jon Elster, Introduction in CONSTITUTIONALISM AND DEMOCRACY 3 (Jon Elster and Rune Slagstad eds. 1988).

${ }^{33}$ Ulrich Preuss, Constitutional Powermaking for the New Polity: Some Deliberations on the Relations between Constituent Power and the Constitution, 14 CARDOZO L. REV. 635 at 641 (1993).
} 
embodying the principles of liberal constitutionalism, is removed from democratic politics. If democracy is only about right outcomes, and if those outcomes are already embedded in a constitutional arrangement and removed from popular discussion and debate, the ideals of openness and popular participation with respect to the fundamental laws are rendered meaningless. On the contrary, democracy insists that all arrangements must be open and fluid at least on regular and mandated occasions.

While the concern in non-democratic societies to "organize political institutions so that bad or incompetent rulers can be prevented from doing too much damage" is understandable, ${ }^{34}$ it is condescending and inappropriate in ostensibly democratic cultures. If ordinary laws and especially fundamental laws do not result from the exercise of popular participation, then there may be talk of good or bad laws, but not of democracy. In a robust democracy, everything is always 'up for grabs' and present institutional arrangements should always be open to revision and replacement, albeit not frequently or haphazardly. It is not a case that 'anything goes', but that anything might go. ${ }^{35}$ With democracy comes risk. But that is both the exhilarating promise and the ever-present danger of democratic governance.

\section{AN HISTORICAL REMINDER}

In proposing his moral reading of the constitution, Dworkin's gamble is not only that judges will be capable of utilizing the appropriate philosophical method, but that they will arrive at the 'right' results or, what is the same thing, those results that he favours. This is as much a strategic and historical claim as a philosophical one. Yet, an observer who is not committed to or even interested in the internal operations of the judicial process might want to assess the judicial interpretation of the

${ }^{34}$ KARL POPPER, THE OPEN SOCIETY AND ITS ENEMIES (1965) vol. 1 at 107.

${ }^{35}$ See Cornelius Castoriadis, The Greek Polis and the Creation of Democracy in CASTORIADIS READER 282 (David Curtis ed. 1997). See also A. HUTCHINSON, IT'S ALL IN THE GAME: A NON-FOUNDATIONALIST ACCOUNT OF LAW AND ADJUDICATION (2000) and ALAN KEENAN, DEMOCRACY IN QUESTION: DEMOCRATIC OPENNESS IN A TIME OF POLITICAL CLOSURE 10 (2003). 
constitution strictly in terms of the actual outcomes reached; the results, not the reasoning, will be the acid-test of the liberal gambit. Consequently, whatever principled or theoretical arguments Dworkin may successfully make about the need to contain popular participation in the name of liberal constitutionalism, his proposals still run up against what he has termed "the brute facts of legal history." 36 Such an historical accounting is far from kind or reassuring to the constitutionalist cause, be it of a liberal or conservative stripe.

Even a cursory glimpse at the historical sweep of constitutional law strongly suggests that the political performance of the courts has been mixed at best. For instance, the roads from Dred Scott to Brown (and perhaps back towards Plessy) and from Lochner to Lincoln Federal (and, again, perhaps back towards Lochner) are chastening ones. ${ }^{37}$ Whether a liberal or conservative, any political enthusiast who takes seriously the historical record ought to have second thoughts about the wisdom of relying on the courts to deliver the democratic goods. Indeed, the Bush v. Gore fiasco -- a decision which Dworkin considers "egregious", "partisan" and "shame[ful]"38 and which robbed democracy of its duly chosen

${ }^{36}$ Dworkin, LAW'S EMPIRE, supra, note 10 at 255.

${ }^{37}$ See Dred Scott v. Sanford, 60 US 393 (1857); Plessy v. Ferguson, 163 US 537 (1896); and Brown v. Board of Education, 347 US 483 (1954). Plessy has experienced something of a renaissance in the form of the rebellion against affirmative action: any resort to racebased categories is treated as invalid. There are echoes of Brown J.'s dissent in Plessy in Thomas J.'s judgment in Adarand Constructors Inc. v. Pena, 512 US 200 (1995). See also G. LOURY, INDIVIDUALISM BEFORE MULTICULTURALISM (1996). As regards Lochner v. New York, 198 US 45 (1905) and Lincoln Federal Labor Union v. Northwestern Iron and Metal Co., 335 US 525 (1949), the decisions in Nollan v. California Coastal Commission, 483 US 825 (1987) and Dolan v. City of Tigard, 114 S.Ct. 2309 (1994) seem to embody a Lochner-style approach. See Note, Resurrecting Economic Rights: The Doctrine of Economic Due Process Reconsidered, 103 HARV. L. REV. 1363 (1989) and Cohen, Lochner in Cyberspace: the New Economic Orthodoxy of 'Rights Management', 97 MICH. L. REV. 462 (1999). For further discussions of these continuing historical episodes, see A. HUTCHINSON, EVOLUTION AND THE COMMON LAW ch.5 (2006).

${ }^{38}$ Dworkin, JUSTICE IN ROBES, supra, note 14 at 23, 101 and 259. See also Bush v. Gore, 531 U.S. 98 (2000). 
presidential representative -- is strong evidence of why Dworkin should be at least skeptical, if not dismissive, of the Supreme Court's capacity and willingness to advance his constitutionalist vision of liberal politics over the long haul. But it is a mistake to approach Bush v. Gore as an unfortunate aberration from an historical liberal script or a conservative exception that confirms the rule that a judicial review is the best way of advancing and protecting liberal democracy. In fact, during the last few years, the Supreme Court has struck down important liberal legislative policies and resisted liberal interventions on individual rights. For example, the Court in Lopez, invalidated a federal criminal prohibition on the possession of guns in local school zones; in Morrison, invalidated the civil damages section of the federal Violence Against Women Act, ruling that acts such as date rape were not economic activities that substantially affected interstate commerce; and in Padilla, declined, on jurisdictional grounds, to rule on whether Padilla could be held indefinitely in military custody as an enemy combatant without being charged. ${ }^{39}$

Accordingly, even if Dworkin's preferred conception of democracy were to be adopted and approved, there are few historical or strategic reasons to prefer a strong system of judicial review over a system of legislative supremacy. As Dworkin himself has expressed, in the current constitutional arrangement, the people and their representatives have to "accept the deliverances of a majority of the justices, whose insight into [controversial and profound questions of political morality] is not spectacularly special. ${ }^{40}$ The risks of injustice or, as Dworkin would put it, wrong and illiberal outcomes seem to be always present. Unlike Supreme Court justices, members of congress at least do not operate behind a dubious curtain of impartiality and can be removed through the ordinary electoral process. After all, in Is Democracy Possible Here, even Dworkin had little choice but to recognize that, since in recent years Supreme Court justices have once again become active in striking down congressional

${ }^{39}$ See United States v. Lopez, 514 U.S. 549 (1995); United States v. Morrison, 529 U.S. 598 (2000); and Rumsfeld v. Padilla, 542 U.S. 426 (2004). See also Padilla v. Hanft, 126 S. Ct. 1649 (2006), where the Supreme Court denied Padilla's petition on certiorari after he was charged with crimes and released from military custody.

${ }^{40}$ Dworkin, FREEDOM'S LAW, supra, note 9 at 74. 
legislation of a liberal pedigree, "liberals are...beginning to rediscover the supposed virtues of the majoritarian conception of democracy" (138).

The idea is not to idealize legislatures. Even Dworkin has some misgivings about the present role and decisions of the present Supreme Court and admits that, although "we must not condemn judicial review as undemocratic whenever we disagree with decisions the court makes", he is "worried about an ideological administration appointing young ideological judges whose tenure on the courts will last for generations" (158): he recommends an encouraging a fifteen-year tenure limit for judges. However, he remains optimistic that this conservative period is an interlude because he notes that in a decade or so "the nation [will have] steered itself back to the middle as, so far, it always has" (158). On the historical record, there is strong support for regular toing-and-froing between liberal and conservative phases, but this is only 'so far' and that prediction can only be of relatively cool comfort to the liberal constitutionalist. There is simply no reliable way to make a historical projection about whether the courts over the next couple of decades will be more or less like the Warren or Rehnquist court. Whether it should or should not be that way as a matter of constitutional rightness, as Dworkin contends, is almost besides the strategic point. Defending a moral and correct reading of the constitution might well be throwing good theoretical money after historical bad. Of course, Dworkin might well insist that it is the burden of constitutionalist "seers and prophets" historical recalcitrance and persuade judges and jurists of the error of their prosaic ways. But this will be a political claim which itself must be anchored in firmer historical ground than the soft sands of prophetic platitude that "Americans of goodwill, intelligence, and ambition have given the world, over the last two centuries, much of what is best in it now" (163).

In referring to the historical record of judicial review, there is another large problem with Dworkin's approach and proposals. In diagnosing that contemporary "degraded politics are not only insulting and depressing; they are not even democratic" (147) and prescribing a strong corrective of

${ }^{41}$ Dworkin, LAW'S EMPIRE, supra, note 10 at 407. 
moral reflection, he fails to consider or comprehend that his preference to place the courts at the democratic heart of the constitutional compact is very much part of the problem, not the solution. In democratic terms, it may not be the case at all that the "constitution ... is one of America's greatest political advantages" (155). Indeed, a continued and heavy reliance on a judicially-enforced constitution might be such a disabling disadvantage that it has contributed to the very degradation of democratic politics that it is supposed to ennoble. If the most important issues of political controversy are routinely placed beyond or withdrawn from popular politics, it should come as no surprise that this will work to promote democratic disaffection by sapping people's political energies and atrophying their participatory instinct. Ironically, this lack of interest in politics in 'large and complex societies' is precisely why the constitutionalists defend non-participatory institutions. Making courts into a primary venue for democratic engagement perpetuates the idea that social justice comes from a judicial act of noblesse oblige rather than a popular product forged in the furnace of political debate. Unless the presently disaffected can become part of their own future empowerment, there can be no confidence that apathy and indifference will not persist. Indeed, Dworkin and his constitutionalist ilk increase the odds that the degradation of politics will become further entrenched.

Finally, an historical awareness suggests a very different appreciation of the relation between constitutional arrangements and prevailing political sensibilities. Constitutions do not speak or act for themselves: their contingent operation and shifting meaning are closely, if complicatedly, connected to broader political forces and democratic dynamics. A constitution will not hold back an overwhelming political impetus: it is only a bulwark against injustice, apprehended or real, if there is a democratic will to interpret or rely on it to do so. Similarly, constitutional decisions which take a firm stand against injustice do not occur or stick unless there is a popular openness to such interventions. Legal efficacy depends on political viability: the ebb and flow of court decisions do not happen in spite of democratic leanings, but, at least in part, because of them. Any juridical order which is not underpinned by a democratic culture, no matter how liberal its constitution and how stringent its procedures for constitutional change, is always at risk of falling victim to 
popular disruption and even rejection. ${ }^{42}$ Conversely, a juridical order which is more consistent with the idea of democratic openness and has a culture of political equality is also at risk, albeit a lesser risk. No constitutional arrangements are acceptable if they can only survive by keeping democratic politics in an institutional straitjacket. As such, liberal constitutionalists like Dworkin over-estimate the instrumental impact of constitutions, even as they tout their symbolic significance.

\section{A DEMocratic Alternative}

It ought to be clear that, while we have sympathy for Dworkin's overall project to salvage democracy from its presently parlous condition, we do not believe that Dworkin's proposals have done much to contribute to that task. Indeed, we maintain that constitutionalists like Dworkin might well be stymieing efforts to develop and substantiate a more progressive and energized democracy than is likely to exist in the near future; 'constitutional democracy' is the failed liberal attempt to balance democracy and constitutionalism. Accordingly, it is incumbent upon us to offer an alternative view of the relation between constitutionalism and democracy so that the ordinary citizenry can become "a full partner in a collective political enterprise" (131). In contrast to Dworkin, we insist that there needs to be a democratic or weak form of constitutionalism. As such, we place our confidence in the claim that, if provided with better and more extensive institutional opportunities to participate in their own governance, people will cultivate a greater appetite and aptitude for political engagement. If domination breeds largely subservients, then democracy will beget mainly democrats. In short, the best way to "reinvigorate the argumentative dimension of our politics" (8) is more democracy, not less. To that end, we will adumbrate a more affirmative case for increased popular participation and then offer a realisable series of modest proposals to achieve that end.

42 The events of 1989 in Europe are an example of how "even powerful and longenduring organizations of state coercion and ideological hegemony fall before radical dissent". Neil MacCormick, Constitutionalism and Democracy in THEORIES AND CONCEPTS OF POLITICS: AN INTRODUCTION 144 (Richard Bellamy ed. 1993). See also Waldron, supra, note 7 at 310 . 


\section{A. BEyOnd LiBeral CONSTitutionalism}

'Democracy' is one of the most relied upon, but least explored terms in the jurisprudential lexicon. Indeed, its malleable and contested nature is a large part of its enduring political appeal. At the heart of the democratic ideal is the understanding that people should rule over themselves. The smaller that the gap is between the rulers and the ruled and between the powerful and the powerless, the better and more democratic that society will be. In 'closing the gap', any sensible democratic theory must pay attention to both the 'formal' and 'substantive' elements of democracy. While it will be essential to ensure that there exist appropriate venues and processes through which people can participate in government and hold it accountable, it will also be equally important to look at the substantive conditions in which people live so that their participation can be relatively equal and robust. As such, electoral participation is not a full or true indication of a society's democratic health. At its starkest, it would be difficult to suggest that a country which extended the vote to all citizens was deserving of democratic accolades if the largest part of the population lived in miserable conditions, with a short life expectancy, and with little education or employment prospects. This would be more travesty of the democratic ideal than its realisation.

Any country which claims to be democratic will be disposed to take measures to facilitate 'closing the gap' between its governing elites and its governed majority. While there is no need or warrant for absolute equality (as this would stifle individual initiative and require constant governmental supervision and readjustment), a commitment to democracy suggests that everyone, not only some and certainly not only a few, should share in the good and bad fortune of that society. To be genuine democratic participants, people must be emancipated from bondage of all kinds, economic, social, and cultural. If the extent of participation by lowly citizens in those power-centres which affect their lives is the measure of democratic progress, the inimitable Aristotle remains pertinent in his judgment that "the real difference between democracy and oligarchy is poverty and wealth. The rich are few and the poor are many ... where the poor rule, that is democracy." ${ }^{, 3}$ Equality of opportunity demands more

${ }^{43}$ ARISTOTLE, POLITICS 1279b40-1280b5 (B. Jowett trans. 1943). It would be less troubling for there to be a maldistribution of substantive resources and opportunities if the 
than the dismantling of formal barriers to participation, it also requires continuing substantive and affirmative measures to actualize those opportunities and possibilities. Consequently, democracy's commitment to equality must be as substantive as it is procedural.

Democracy is better thought of as a social way of life in which everything that affects the conditions of people's lives is potentially encompassed; democracy is a value and process which can inform all aspects of social life. Viewed this way, democracy is the commitment par excellence to the idea that almost all choices and actions have political roots and political consequences: people can tackle those politics within a framework within which their active participation is more important than (or, at least, as important as) that of elected representatives and appointed elites of political sages. In particular, democracy need not be construed as simply a set of processes and practices tagged on to a particular political ideology, whether it be liberalism, conservatism, socialism, or whatever. Indeed, democracy is a mode of life, an ethos, a way of day-to-day living within which the best of such ideologies and political commitments can be harnessed and their excesses jettisoned. In that sense, the robust brogue of democratic politics insists that the liberal or socialist is only one kind of democrat and that the democrat is not only one kind of liberal or socialist.

Accordingly, our approach to democracy is very strategic and political; it is not conceptual or philosophical in Dworkin's sense. Rather than talk in absolute terms about the overall democratic quality of society, it is preferable to concentrate on those measures which are proposed to be taken to make a society more democratic. From this standpoint, 'democracy' is not a black-and-white idea or practice; a society is not either democratic or undemocratic. It is a matter of shading and degree.

most recent trends were towards reducing or modifying it. However, over the past decade or so, the trend has been in the opposite direction -- the extent of inequality in wealth and income is getting worse and the gap between the haves and the have-nots is increasing. For instance, in the last 25 years up to 2004, not only were income gains more concentrated at the top of the income scale, but the average after-tax income of the richest fifth rose by about $100 \%$ as compared to about $5 \%$ for the poorest fifth. See CONGRESSIONAL BUDGET OFFICE, HISTORICAL EFFECTIVE FEDERAL TAX RATES: 1979 TO 2004 (December 2006). By any sort of democratic standard, this decline (as opposed to the absolute level of inequality) is profoundly troubling. 
While it will be necessary to make trade-offs within a democratic society (i.e., as between distribution and production, freedom and equality, etc.), it is unnecessary and ill-advised to make trade-offs with democracy. To think in such terms is to misunderstand democracy. Consequently, rather than think about democracy as one particular thing or to evaluate a state of affairs as being democratic or not, it is better to ask whether taking a particular step is likely to advance democracy; this will be a contextual and contingent assessment. As such, the type of democratic commitment which we defend is pragmatic and contingent rather than idealistic or absolutist. The primary consideration in any effort to effect change will always be -- what present measures will best increase the greater participation and control which people have over those institutions and practices which most affect their lives today? ${ }^{44}$ While it is better that more are involved more of the time than less are involved less of the time, it seems counter-productive to deny a reform proposal or strategy the term 'democratic' because it does not involve everyone all the time; it is a democratic mistake to let the best be the enemy of the good.

That being the case, it is possible to highlight several strategic and pragmatic commitments against which any particular proposal or reform to advance the democratic project can be assessed. These are what we shall call 'the four basic precepts of democratic advancement'. Taken together, they confirm the emancipatory and transformative potential that lies within democracy. :

1. more extensive participation is better than less extensive -- because democracy is as concerned with the pedigree of power as its effects, any state of affairs which multiplies and broadens the number of locations, whether public or private, in which participation is possible is more likely to advance democracy than not:

2. more participation is better than less participation-- because involvement is a benefit in itself and can beget a taste for even further involvement, any state of affairs which increases the degree

44 See A. HUTCHINSON, THE COMPANIES WE KEEP: CORPORATE GOVERNANCE FOR A DEMOCRATIC AGE (2006). 
of direct as well as indirect or substantive as well as formal participation is more likely to advance democracy than not:

3. more equal participation is better than less equal participation -because people experience a sense of genuine participation only if their involvement is effective and counts, any state of affairs which tends to ensure that no one has more power than any one else is more likely to advance democracy than not;

4. more responsibility is better than less responsibility -- because people cannot be expected to be involved all the time in all locations in all circumstances, any state of affairs which renders those with temporary power more accountable to others is more likely to advance democracy than not.

Democracy does not have all the answers to life's challenges. Indeed, democratic theory embraces the idea that there are no once-and-for-all right answers and nurtures a practice which seeks to accommodate difference of opinion rather than do away with it. As evidenced by Dworkin and other liberal constitutionalists, democracy has too often been viewed as more the icing on the political cake than part of the cake itself; it has been used to serve interests other than its own. Indeed, the constant pressure to constrain and cabin democracy is plain evidence of a fearful acknowledgment of democracy's power to subvert the status quo and, in particular, to threaten the power of various entrenched elites. By ensuring that democracy's broad mandate (i.e., including social and economic as well as political matters) and deep mandate (i.e., requiring regular sustained acts of participation) are both respected, it will better ensure that the citizenry become "a full partner in a collective political enterprise" (131) and that it is possible to "reinvigorate the argumentative dimension of our politics" (8). To do this demands that there are greater efforts to pluralize and circulate the sites and situations in which democracy is at work: it is not possible to have "democracy with a Big D in the system as a whole if you do not have real democracy with a small $d$ at the level where people live, work, and raise families in their local communities.",45

${ }^{45}$ GAR ALPEROVITZ, AMERICA BEYOND CAPITALISM: RECLAIMING OUR WEALTH, OUR LIBERTY, AND OUR DEMOCRACY 43 (2005). 
By being flexible and pragmatic, democrats can accept that compromise as well as conviction are important qualities. However, those four precepts outlined can help bridge the existing divide between democracy's past and future, between its commitment and achievement, and between its vision and reality. In particular, they can better inform the project of democratic renewal in the constitutional context.

\section{B. Some Constructive Proposals}

Democrats stand for all that constitutionalists fear. Unlike constitutionalists, they do not contend that the purpose of constitutional democracy is to protect democracy from itself. ${ }^{46}$ Indeed, constitutionalists only manage to pass themselves off as democrats because they shave the idea of democracy so thin that they transform constitutionalism into the democratic telos. In contrast to the slender and diluted offerings of such constitutionalists, democrats maintain that 'rule by the people' recommends at least two general and indispensable commitments on the constitutional front -- (1) an institutional openness in which even the most fundamental principles are open for discussion and are always susceptible of being reformulated or replaced and (2) empowering a group of human beings so that they come together in political equality and settle on the laws that will regulate the institutions and practices under which they live. In order to for these rules to be the people's own, it must be today's people who rule, not past generations: the constitutionalist idea of precommitment cannot be brought to a final reconciliation with democracy. Consequently, while a self-governing people must be able to reformulate their commitments for themselves and do so by democratic means, 'openness' must of necessity be limited openness. For there to be critique and revision, some basic threshold of institutional structure and individual entitlement (e.g., open elections, balanced constituencies, access to information, etc.) which make such democratic activities possible must be in place. However, these limits to democratic openness, are the limits of democracy itself.

\footnotetext{
${ }^{46}$ See STEPHEN HOLMES, PASSIONS AND CONSTRAINT: ON THE THEORY OF LIBERAL DEMOCRACY (1995).
} 
In this effort to de-sacralize and de-frost the constitutional order, there are a number of strategies that might be adopted so as to redress better the traditional balance between constitutionalism and democracy. Although they by no means exhaust the possibilities for tapping into and engaging the transformative potential of the citizenry that is presently suppressed, these initiatives might include:

1. A Reduction in the Powers of the Courts -- The concern with granting the judiciary the power to strike down legislation is not restricted to academic critiques about the legitimacy of judicial review. It has received several institutional responses throughout the world: courts can rule on, but not rule out government acts which are considered to offend the constitution. In the United Kingdom, for example, a court may issue a "Declaration of Incompatibility" if it is convinced that a legislative enactment is incompatible with one of the rights enumerated in the European Convention of Human Rights which has been incorporated into domestic British law. Such a declaration does not mean the statute in question is invalidated or that Parliament is required to respond in anyway: the legislation continues to have full validity, but the declaration has the effect of empowering the relevant minister to initiate a 'fast-track' legislative procedure to amend the statute in question. $^{47}$. New Zealand's approach grants even less power to courts. Courts are not only expressly forbidden from striking down a statute that is deemed inconsistent with enumerated rights, but they are required, whenever possible, to interpret statutes in a way that is consistent with the recognized rights and freedoms. Because declarations of incompatibility rely on their political and symbolic effect to promote change, these Commonwealth innovations are more compatible with the democratic project. ${ }^{48}$ The importance of this kind of proposal is that it not only speaks to the legitimacy of judicial review in terms of the so-called 'counter-majoritarian

${ }^{47}$ Human Rights Act (U.K.), ss. 4 and 10. See generally Stephen Gardbaum, The New Commonwealth Model of Constitutionalism [2001] AM. J. OF COMP. LAW 49.

${ }^{48}$ Bill of Rights Act of 1990 (N.Z.), ss.4 and 6. See also The Queen v. Pora, [2001] 2 NZLR 37, The Queen v. Poumaki, 2 NZLR 695. 
difficulty', but that it recognises that popular participation suffers when society's most important political controversies are left in the hands of an elite body of legal experts.

2. Establish a Separate Constitutional Court -- In combination with reducing the courts' powers, it would also be advisable to change the organisation of the courts and their personnel. Rather than give ordinary courts the power to review the constitutionality of government acts, it would be more in line with a democratic project to establish separate and specialised constitutional courts which had exclusive authority to do so. Such a practice has a relatively long history and has been particularly attractive to states emerging from fascist or oppressive regimes. For instance, South Africa has adopted such a model in its post-apartheid governance. ${ }^{49}$ In fulfilling this mandate, the court could have the power to perform traditional review as well as entertaining advisory and non-binding references from government on proposed policies. Although many of the actual constitutional courts in existence are typically staffed by state-appointed judges, it would also be possible to think of such agencies as being 'constitutional councils' rather than courts. The membership of such bodies might well be more mixed and representative. For instance, councillors could be elected for a lengthy, but designated period and have qualifications which do not include being legally-trained. Such reforms would not only enhance the democratic legitimacy of the courts, but it would also bring a broader set of professional skills and judgments to the exercise of the council's constitutional responsibilities.

3. Creation of a Legislative Override -- The ideas of taking away from courts the power of striking down 'rights-violating' legislation or re-organising the courts and their personnel might be too threatening to the American constitutional tradition.

${ }^{49}$ See HEINZ KLUG, CONSTITUTING DEMOCRACY: LAW, GLOBALISM AND SOUTH AFRICA'S POLITICAL RECONSTRUCTION (2000) and TOM GINSBERG, JUDICIAL REVIEW IN NEW DEMOCRACIES: CONSTITUTIONAL COURTS IN ASIAN CASES (2003). 
Consequently, a less disruptive alternative would be to give Congress a genuine power to override judicial decisions which invalidated legislation. This power would be similar to the 'notwithstanding' provisions of the Canadian Charter of Rights and Freedoms. Incorporated as an indispensable part of the political bargain which facilitated the introduction of the Charter itself in 1982, this provision enables the federal and the provincial legislatures to override for a renewable period of five years, by simple majority, the rights contained in the Charter. ${ }^{50}$ However, we maintain that the preferable legislative override would operate only after a judicial opinion has been rendered: the legislature would then have the choice of overriding that judicial decision through the same process by which ordinary legislation is adopted. For this constitutional device to work effectively, it must not be viewed as the last resort of an intransigent legislature that is intent on violating people's rights. On the contrary, it should be recognized as an essential feature of democratic politics by which an elected assembly declares that it is not ready to give jurists the final word on particular contested policies. The democratic balance of power would countenance against the results of the legislative process being subordinated to the legal expertise of a judicial body. Moreover, such a dynamic interplay would presumably influence for the better the performance of the courts in fulfilling their traditional constitutional role.

4. Introduce Periodic Constituent Assemblies -- The fact that past generations establish constitutional provisions which are extraordinarily difficult to amend or revise has always been a matter of considerable chagrin for democrats. As an institutional solution to this problem, Thomas Jefferson suggested that every so

50 Constitution Act 1982 (Can.), s.33. As the Canadian experience with s.33 has demonstrated, this kind of mechanism can quickly become a constitutional relic if the political price of invoking it is too high. In fact, apart from the exceptional case of Quebec, s.33 is rarely invoked in Canada and, since its inception, a constitutional convention has emerged according to which the "notwithstanding" clause should hardly, if ever, be used. For a summary of its use and subsequent development, see Peter H. Russell, Standing Up For Notwithstanding, (1991) 29 ALTA. L. REV. 293 and PETER HOGG, CONSTITUTIONAL LAW OF CANADA 815-19 (2002). 
often all fundamental laws and institutional arrangements should lapse and periodic assemblies convened so that each generation had the "right to choose for itself the form of government it believes most promotive of its own happiness." fits well with our efforts to combine strong democracy with weak constitutionalism. A periodic constituent assembly every 35 or 40 years would allow people to claim the constitution as their own and to keep it in tune with the citizenry's changing values. As importantly, it will also oblige citizens to debate and take responsibility for the deep structure of their political society. Such assemblies could be composed of delegates selected in a nationwide special election; membership could be limited to people who are not members of the ordinary legislature and who are more broadly drawn from different sectors of civil society. The deliberations of the assembly could be public and its proposals would have to be ratified by the majority of the citizens in a national referendum. During what is likely to be a lengthy deliberation period, the old constitutional rules would continue to apply. Also, because political exigencies may demand more frequent assemblies, a special procedure might be required to allow citizens to petition directly for the convocation of a constituent assembly that would re-draft or make important changes in the constitution. This might demand that a petition be signed by $15 \%$ or so of the adult population and presented to the ordinary legislature which would then be legally obliged to call a referendum to determine if a constituent assembly should occur.

These proposals separately and together will no doubt perplex constitutionalists like Dworkin as they might promote constant constitutional change and, thereby, offer a challenge to juridical preeminence and stability. Yet to the democrat, they are nothing more than

${ }^{51}$ THOMAS JEFFERSON, WRITINGS 1402 (Merrill Peterson ed. 1984) at 1402. Using the European tables of mortality, he calculated that a new generation comes into place every nineteen years. In a similar vein, Thomas Paine stated that "every age and generation must be as free to act for itself, in all cases, as the ages and generations that preceded it". Thomas Paine, The Rights of Man in THE LIFE AND MAJOR WRITINGS OF THOMAS PAINE 251 (Philip Foner ed.1961). 
a natural corollary of a strong commitment to the ideal of self-government. A failure to take seriously these proposals exposes constitutionalists' weak and begrudging embrace of democracy.

\section{When Hercules Met Alexis}

Many constitutionalists would conceive Lycurgus as the reluctant embodiment of their theoretical and practical ambitions. ${ }^{52}$ According to Greek legend, Lycurgus was the 'founding father' of the Spartan constitution. Before visiting the Delphic oracle, he called an assembly of the people and made everyone, including the kings and senators, promise not to tinker with the constitution until he returned. When the oracle told him that the constitution was well-written, Lycurgus starved himself to death; he also had his ashes scattered in the ocean so that it could never be claimed that he had returned in any form. The Spartans kept their promise and the constitution remained unaltered for 500 years. However, despite his championing by present-day constitutionalists, debate still rages as to whether Lycurgus had made the ultimate and heroic sacrifice for his Spartan compatriots or whether he had in fact sacrificed them to his own vanity. In many ways, this cautionary legend captures the institutional quandary of those contemporary jurists and theorists who struggle to choose between the competing pushes and pulls of constitutionalism and democracy.

It should not come as a surprise to legal scholars to learn that Lycurgus was a direct and eleventh-generation descendant of the fabled Hercules (which was the Roman name for the greatest hero of Greek mythology, Heracles). Of course, apart from his fabled exploits in fighting monsters and performing physical feats of strength, Hercules is also Dworkin's "imaginary judge of superhuman intellectual power and patience." such, he is one of jurisprudence's mythic titans who is intended to offer an

${ }^{52}$ See, for example, Dennis Thompson, Democracy in Time: Popular Sovereignty and Temporal Representation, 12 CONSTELLATIONS 251 (2005).

${ }^{53}$ Dworkin, LAW'S EMPIRE, supra, note 10 at 239 and JUSTICE IN ROBES, supra, note 14 at 55-56 and 67-68. 
idealized version of what Dworkin-instructed judges might seek to emulate, even if they are destined always to fall short of his transcendent example. While neither Lycurgus nor Hercules make an appearance in Is Democracy Possible Here?, their colossal personae and influence are present throughout. Yet such epic figures are antithetical to any ideal or practice of engaged democracy; they give the distinct impression that truth and justice are not achievable by ordinary people, that it takes extraordinary abilities to create and interpret constitutions, and that debate and deliberation are superfluous to a fully-realised civic society. Progress is considered to be more a gift from the gods than anything else. In short, the invocation of Lycurgian and Herculean qualities in guiding contemporary politics works to trivialize and discourage popular participation in democratic governance.

Because too much legal scholarship already seems to be populated by such super-heroes and their antics, we are reluctant to add another to their ranks. Democracy certainly does not need another hero in the Herculean or Lycurgian tradition. Indeed, there needs to be a wholesale revision in the thinking about what leadership demands in a political tradition which is informed and inspired by democracy. The traditional and largely demagogic notion of 'political leaders' is anathema to a democratic sensibility; it conveys images of unquestioned authority, complaint obedience, testosteronic endeavour and hierarchical superiority. In place of this cult of leadership in which society's fate seems to be tied almost exclusively to the identity and qualities of its leaders, it is important to develop a more appropriate and lower-key notion of leadership. However, if democracy were to have a prototypical leader, it might be the eponymous 'Alexis' who can stand in for the ordinary citizen of the truly democratic polity.

Alexis is a modest and gregarious person. $\mathrm{S} / \mathrm{he}$ recognises that, if $\mathrm{s} / \mathrm{he}$ is a leader, $\mathrm{s} /$ he is a reluctant one at that. Although possessing similar energies and dynamism to more traditional leaders, $\mathrm{s} / \mathrm{he}$ channels that into more popular pursuits. S/he is a good listener and seeks to engage with rather than mold fellow citizen's views. However, Alexis is sufficiently sensitive to context that $\mathrm{s} / \mathrm{he}$ is aware that "the surface of American society is covered with a layer of democratic paint, but from time to time one can 
see the old aristocratic colours breaking through." ${ }^{54}$ Eschewing the elite accents of the society's power-centres, s/he travels widely and keeps company with a wide range of people from diverse backgrounds. Most importantly, Alexis appreciates that democratic leaders are enablers, not enforcers. S/he acts on the idea that democratic leaders are not ones who impose their own personal vision to attain a shallow and fearful consensus. Rather, they help to facilitate the community's efforts at building and implementing its own democratic culture. As such, Alexis knows that "it takes time to arouse minds from apathy and lethargy, to get them to thinking for themselves, to share in making plans, and to take part in their execution." ${ }^{, 55}$ Moreover, more humble than hubristic, Alexis is willing to stand aside and let the people take the credit for their own achievements; $\mathrm{s} /$ he recognises that there is no One Right Way and that what prevails today might well be rejected tomorrow. S/he is truly a person of the people.

\section{CONCLUSION}

Is Democracy Possible Here? deserves strong praise because it puts the important and intimate relationship between constitutionalism and democracy at the centre of both jurisprudential and legal debate. Ronald Dworkin tackles some of the most pressing matters on the political agenda and does so in a sustained, practical and courageous way. As such, he has succeeded in his ambition to "reinvigorate the argumentative dimension of our politics" (8). Yet his contribution also deserves strong criticism because it is the way that he has framed the general argument as much as the specific positions that he has taken which prevent the reasonable likelihood of there being genuine progress beyond the "degraded politics" (147) of American and many western democracies today. Democracy cannot and should not be exhausted by a liberal constitutionalism. By embracing constitutionalism's Lycurgian and elitist tendencies and by

${ }^{54}$ ALEXIS DE TOCQUEVILLE, DEMOCRACY IN AMERICA vol 1, part 1, ch.2 (Henry Commager ed. 1946).

55 J. DEWEY AND J. TUFTS, ETHICS 385 (rev. ed. 1936). See, also, ADEL SAFTY, LEADERSHIP AND DEMOCRACY (2004). 
rejecting democratic openness and enhanced participation, constitutional democrats support a weak version of democracy. In contrast, we have proposed upsetting the supposed balance between constitutionalism and democracy and replacing it with a stronger version of democracy. Democracy ought not to be seen as a form of government embodied in a constitution because democracy always escapes constitutionalization. Instead, democracy should be advanced as a substantive manifestation of popular sovereignty.

We can end, therefore, where we began with Dworkin's titular question -Is Democracy Possible Here? For Dworkin, even though democracy is presently under siege and in poor health, its realisation remains entirely possible because the adjustments needed are more those of tone and substance than structure or transformation. For us, democracy will only be possible if there is a willingness to move beyond its presently anaemic and weak form and to engineer changes that bring it closer to its more fullbloodied potential. This democratic ideal recommends that a constitution is a part of a vigorous democracy, not something separate and aside from it, and that the 'sovereignty of the people' does not end in the act of constitution-making. A commitment to democracy presupposes a political terrain that is never closed. Unlike constitutionalism, it places a society's citizens, not its judicial or philosophical consuls, at the heart of the political process. 